\title{
Tradeoffs between Water Uses and Environmental Flows: A Hydroeconomic Analysis in the Ebro Basin
}

\author{
Daniel Crespo ${ }^{1} \cdot$ Jose Albiac $^{1}$ (D) - Taher Kahil ${ }^{2} \cdot$ Encarna Esteban $^{3} \cdot$ Safa Baccour $^{1}$ \\ Received: 19 October 2018 / Accepted: 1 April 2019 / \\ Published online: 16 April 2019 \\ (C) The Author(s) 2019
}

\begin{abstract}
Environmental water uses and their social values have been mostly overlooked in traditional water management over the last few decades, and recently, the maintenance of environmental flows has been considered a key issue in water policies. Addressing the more sustainable management of water resources involves introducing new water allocation policies. However, these policies are often associated with tradeoffs across sectors, stakeholders, and spatial locations. This study aims to evaluate the tradeoffs and political economy aspects of allocating water among economic water uses and environmental flows in water-scarce river basins. An empirical analysis has been conducted in the Ebro River basin (Spain) as a case study, where an intense debate on the environmental flow allocation of the Ebro mouth is taking place. The study uses a hydroeconomic model that includes the major water uses in the Ebro to analyze the effects of different water allocation policies under combinations of water availability and environmental flow scenarios. The results of this study highlight the importance of assessing the opportunity costs and political implications of reallocating water from economic activities to the environment under impending climate change impacts. Moreover, the results indicate that well-functioning water allocation policies should be not only economically efficient but also socially acceptable to reduce the likelihood of failure of water reallocation to the environment.
\end{abstract}

Keywords Environmental flow · Drought · Water policy $\cdot$ Hydroeconomic modeling $\cdot$ Ebro Basin

JEL Codes Q25·Q54·D78·C61

Electronic supplementary material The online version of this article (https://doi.org/10.1007/s11269-01902254-3) contains supplementary material, which is available to authorized users.

Jose Albiac

maella@unizar.es

Extended author information available on the last page of the article 


\section{Introduction}

Global water extractions have become increasing rapidly in recent decades to sustain a larger population and more prosperous economies (Biemans et al. 2011; Liu et al. 2017). This growing pressure on water resources has created widespread water scarcity problems in many basins around the world, indicating that water mismanagement is quite common. Indeed, sustainable management of river basins worldwide is a complex and difficult task. The upcoming water management problems are especially acute in arid and semiarid regions, where the combined effects of human-induced and climate changeinduced water scarcity and droughts portend unprecedented levels of water resource degradation in the absence of remediating water policies (Albiac 2017; Greve et al. 2018; Yan et al. 2018).

Policies implemented to address water scarcity in water-stressed basins frequently fail because of the lack of accurate assessments of the economic and environmental tradeoffs associated with water allocation decisions. Traditionally, environmental water use and its social values have been mostly overlooked in water allocation decisions (Booker et al. 2012). However, the severe ecosystem degradation of basins across the world in recent decades calls for implementing policies that specifically protect ecosystems such as the establishment of minimum environmental flow requirements. An example is the case of Europe, where water legislation emphasizes the objective of maintaining a good ecological status for all water bodies.

Environmental flows sustain aquatic ecosystems, which provide a diverse range of goods and services to societies, including habitats for valuable species, flood control, groundwater replenishment, water quality improvement, waste disposal, and recreational opportunities. The determination of which ecosystems should be preserved determines the regime of the required environmental flows, implying tradeoffs among water allocations for human uses and environmental flows (Acreman 2016). Experiences regarding these tradeoffs in basins around the world suggest that water uses for irrigation, domestic and industrial purposes usually have much higher priority over environmental flows, especially in arid and semiarid regions. The consequence of this allocation decision has been a severe biodiversity decline in aquatic ecosystems that exceeds by far that of terrestrial and marine ecosystems (Arthington 2012).

This paper evaluates the tradeoffs and political economy aspects of allocating water among water use sectors and environmental flows in water-scarce river basins. To meet this objective, we have developed a hydroeconomic model for the Ebro basin in Spain that incorporates a water allocation system with multiple water use sectors and various hydrological and infrastructure constraints. This model has been used to analyze the effects of three different water allocation policies: upstream priority, proportional sharing, and water markets, to meet different environmental flow constraints under various water availability scenarios.

This paper contributes to the previous literature by dealing with a complex water resource management problem at the basin scale, which includes several levels of pressure (increasing environmental flow requirements and climate change impacts), conflicts (between water use sectors and environmental flows, and between states), and policy interventions (different water allocation policies). The results of this paper highlight the importance of assessing the opportunity cost and political implications of reallocating water from economic activities to the environment under impending climate 
change impacts. Moreover, the results indicate that reallocation efforts require the implementation of not only economically efficient but also socially acceptable policy interventions. In this paper, the Ebro basin is used as an illustrative case study, and the results of this empirical application could provide highly relevant insights to other river basins in the world spanning multiple jurisdictions that face similar water scarcity constraints and competition between water use sectors and environmental flow needs.

The paper is organized as follows. First, we briefly summarize the main issues with water management in the Ebro basin in section 2. Section 3 presents the development of the hydroeconomic model for the Ebro basin. Section 4 describes the model application and the main results of the hydroeconomic analysis, and section 5 discusses the main findings. Finally, section 6 summarizes the main conclusions.

\section{The Ebro River Basin}

The Ebro basin is located in northeastern Spain, covering $85,000 \mathrm{~km}^{2}$ and sustaining the economic activities of 3.2 million inhabitants (Figure SM1.1 in Online Supplementary Material). Available renewable water resources amount to $14,600 \mathrm{Mm}^{3}$ per year, and water withdrawals are $8460 \mathrm{Mm}^{3}$, divided between $8110 \mathrm{Mm}^{3}$ of surface water diversions and $350 \mathrm{Mm}^{3}$ of groundwater extractions (CHE 2015). Water withdrawals for agriculture are approximately $7680 \mathrm{Mm}^{3}$, covering 700,000 ha of irrigated crops (mainly alfalfa, corn, barley, wheat, rice and fruit trees). Withdrawals by water companies supplying urban centers are $630 \mathrm{Mm}^{3}$, and direct withdrawals by industries are $150 \mathrm{Mm}^{3}$. There are also nonconsumptive withdrawals for the cooling of thermoelectric power plants $\left(3100 \mathrm{Mm}^{3}\right)$ and for hydropower production $\left(38,000 \mathrm{Mm}^{3}\right)$.

The management of these water resources is conducted by the Ebro Basin Authority (Confederación Hidrográfica del Ebro). The water authority is in charge of developing the Ebro River Plan, setting the medium-term management strategies, where the objectives are to fulfil water demands, contribute to regional development, and protect the ecosystems in the basin. Ecosystem protection is implemented by establishing minimum environmental flows in selected river reaches.

The distinctive feature of this institutional-based approach is the key role played by stakeholders. All water stakeholders (i.e., water users, public administrations and environmental groups) are represented inside the water authority. These stakeholders' representatives are involved in all governing and participation bodies at the basin scale, and they run the watershed boards at the local scale. An important issue in the Ebro basin in recent decades is the conflict between the upstream states (Aragón, Rioja, Navarra, País Vasco) and the downstream state (Cataluña) because of the minimum environmental flow requirements at the Ebro mouth. The Ebro and the Duero rivers are the only rivers in Spain with substantial minimum environmental flows at the river mouth, which are approximately $20 \%$ of natural streamflows compared with the minimum flows of approximately $0.1-4 \%$ in the rest of the basins.

Despite this significant minimum environmental flow threshold in the Ebro, Cataluña is asking for a steep increase in minimum environmental flow in normal years from the current 3000 up to approximately $8000-9000 \mathrm{Mm}^{3} /$ year, increasing the share allocated towards natural streamflow from $20 \%$ up to $50-65 \%$. These extraordinary requests by the downstream Cataluña state are opposed by all upstream states in the basin since their water-related economic activities would be seriously damaged. 


\section{The Hydroeconomic Model of the Ebro Basin}

A hydroeconomic model of the Ebro basin is developed to analyze the current water allocation by sector and spatial location in the basin. The model integrates the hydrology, economic activities, and environmental flows of the basin. The hydrological component is a node-link network of supply nodes, such as rivers and dams, and demand nodes, such as irrigation districts, urban centers, and environmental flows. The regional economic component includes irrigation activities and urban and industrial activities. Irrigation activities are represented using a detailed farm-level optimization module. Urban and industrial centers are represented with an optimization module of the social surplus derived from the supply and demand of water. The environmental use of water is represented by several minimum environmental flow constraints, given the lack of information on the response of environmental benefits to the allocation of environmental flows (Momblanch et al. 2016). The full hydroeconomic modeling framework showing the interactions among the model components is depicted in Figure SM2.1 (Online Supplementary Material).

\subsection{Reduced Form Hydrological Component}

The reduced form hydrological component is built with information from the Ebro basin authority (CHE 2007, 2015) using data on streamflows and water allocations during normal climatic conditions. The hydrological component represents water flows among supply and demand nodes using the basic hydrological concepts of mass balance and continuity of river flows (Figure SM1.2 in Online Supplementary Material). The hydrological component is used to estimate the volume of available water for economic activities after fulfilling the restrictions on environmental flows. The mathematical formulation is as follows:

$$
\begin{gathered}
W_{\text {outd }}=W_{\text {in }}-W_{\text {loss }_{d}}-D i v_{d}^{I R}-D i v_{d}^{U R B} \\
W_{\text {in }_{d+1}}=W_{\text {out }_{d}}+r_{d}^{I R} \cdot\left(\operatorname{Div}_{d}^{I R}\right)+r_{d}^{U R B} \cdot\left(\operatorname{Div}_{d}^{U R B}\right)+R O_{d+1} \\
W_{\text {out }} \geq E_{d}^{\min }
\end{gathered}
$$

where Equation (1) is the mass balance equation, indicating that water outflow $W_{\text {out }_{d}}$ from a river reach $d$, is equal to water inflow $W_{i n_{d}}$ minus the loss of water $W_{\text {loss }_{d}}$, and minus the diversions for irrigation $\left(D i v_{d}^{I R}\right)$ and urban and industrial uses $\left(D i v_{d}^{I R}\right)$. Equation (2) is the continuity equation of river flow that indicates the water inflow to the next river reach $\mathrm{Win}_{\mathrm{d}+1}$ is the sum of outflow from upstream river reach $W_{\text {out }_{d}}$, return flows from the upstream irrigation districts $\left[r_{d}^{I R} \cdot\left(D i v_{d}^{I R}\right)\right]$, return flows from urban centers $\left[r_{d}^{U R B} \cdot\left(\operatorname{Div}_{d}^{U R B}\right)\right]$, and runoff entering that river reach from tributaries $R O_{d+1}$. Equation (3) states that the water outflow $W_{\text {out }_{d}}$ from a river reach $d$ must be greater or equal to the minimum environmental flow requirements $E_{d}^{m i n}$ in that river reach.

The calibration of the hydrologic component is made by adjusting the model parameters to reproduce the observed streamflows under baseline conditions. This calibration procedure involves introducing slack variables that represent unmeasured sources or uses of water to balance supply and demand at each node. Headwater inflows, gauged streamflows and canal 
releases in the basin have been obtained from the Ebro Basin Authority and the Ministry of Agriculture for the period 2000-2014 (CHE 2009; CEDEX 2016).

\subsection{Economic Component}

The economic component includes optimization models for each irrigation district and an optimization procedure of social surplus for the provision of water to each urban center. The optimization model of agricultural activities represents the crop production of the main irrigation districts in the basin (Figure SM1.1 in Online Supplementary Material). This model maximizes the private benefits to farmers from crop production activities for each irrigation district, subject to various technical and resource constraints. For simplicity, it is assumed that yield functions are linear and decreasing, and input and output prices are constant. The problem is formulated as follows:

$$
\operatorname{Max}\left(B_{k}^{I R}\right)=\sum_{i j} C_{i j k}^{\prime} X_{i j k}
$$

subject to

$$
\begin{gathered}
\sum_{i} X_{i j k} \leq \text { Tland }_{k j} ; j=\text { surface, sprinkle, drip } \\
\sum_{i j} W_{i j k} X_{i j k} \leq \text { Twater }_{k} \\
\sum_{i j} L_{i j k} X_{i j k} \leq \text { Tlabor }_{k}
\end{gathered}
$$

$$
X_{i j k} \geq 0
$$

where $B_{k}^{I R}$ is private benefit in irrigation district $k$, and $C_{i j k}^{\prime}$ is net income per hectare of crop $i$ under irrigation technology $j$. The decision variable in this problem is $X_{i j k}$, the area of crop $i$ under irrigation technology $j$. Equation (5) is the land constraint representing the land available in each irrigation district $k$ equipped with irrigation technology $j$, Tland $d_{k j}$. The Equation (6) represents the water available for each irrigation district $k, T_{\text {water }_{k}}$, where $W_{i j k}$ is gross water requirement per hectare of crop $i$ under technology $j$. The water constraint level is the connecting variable between the optimization model of irrigation districts and the hydrological component. The labor constraint (7) represents labor availability in irrigation district $k$, Tlabor $_{k}$, where $L_{i j k}$ is the labor requirement per hectare of crop $i$ under irrigation technology $j$. The suitable irrigation systems are assumed to be surface and sprinkle irrigation for field crops and surface and drip irrigation for fruit trees and vegetables.

The net income per hectare $C_{i j k}^{\prime}$ is the difference between revenue and costs and is defined as follows:

$$
C^{\prime}{ }_{i j k}=P_{i} Y_{i j k}-C P_{i}
$$

where $P_{i}$ is the price of crop $i, Y_{i j k}$ is the yield of crop $i$ under technology $j$ in district $k$, and $C P_{i}$ are the production costs of crop $i$. The model includes the Ricardian rent principle of decreasing yields when additional land enters production. The yield function is linear and decreasing in the area of crop i under technology $\mathrm{j}$ as follows: 


$$
\mathrm{Y}_{\mathrm{ijk}}=\beta_{0_{\mathrm{ijk}}}+\beta_{1 \mathrm{ijk}} X_{\mathrm{ijk}}
$$

The optimization model is calibrated with the positive mathematical programming (PMP) method using the procedure of Dagnino and Ward (2012). This procedure involves the estimation of the parameters of the linear yield function [Equation (10)], based on the firstorder conditions for profit maximization. The data on yields, prices, crop water requirements, production costs, availability of water, land and labor, together with the information on biophysical parameters, have been obtained from statistical databases and previous studies (MARM 2010; MAGRAMA 2016; INE 2009; DGA 2009; GC 2009; GN 2009).

In urban use, the procedure is to maximize the economic surplus, adding the consumer and producer surpluses from the main urban centers in the basin. The optimization problem is expressed as follows:

$$
\operatorname{Max}_{u}^{U R B}=\left(a_{d u} Q_{d u}-1 / 2 b_{d u} Q_{d u}^{2}-a_{s u} Q_{s u}-1 / 2 b_{s u} Q_{s u}^{2}\right)
$$

subject to

$$
\begin{aligned}
& Q_{d u}-Q_{s u} \leq 0 \\
& Q_{d u} ; Q_{s u} \geq 0
\end{aligned}
$$

where $B_{u}^{U R B}$ is the consumer and producer surplus of urban center $u$. The variables $Q_{s u}$ and $Q_{d u}$ are water supply and demand in urban center $u$. The parameters $a_{d u}$ and $b_{d u}$ are the intercept and slope of the inverse demand function, and parameters $a_{s u}$ and $b_{s u}$ are the intercept and slope of the supply function. Equation (12) states that water supply must be greater than or equal to the demand. The water supply $Q_{s u}$ is the variable connecting the urban model with the hydrologic component. Water demand parameters for urban centers are based on the studies by Arbués et al. (2004) and Arbués et al. (2010).

\subsection{Environmental Component}

Environmental benefits from ecosystems services can be represented by modeling the ecological response of these systems to water flows and by imputing an economic value to the goods and services they provide. However, to the best of our knowledge, the representation of environmental benefits in hydroeconomic models is still quite limited. Some studies have included the water consumption of ecosystems in hydroeconomic models (Ahmadi et al. 2012; Connor et al. 2013), but the insufficient knowledge on the response of the ecosystems to water and the lack of information on the economic benefits of ecosystems prevents the inclusion of ecosystems in hydroeconomic modeling. When the ecological response functions to water and the economic valuation studies are not available, a useful alternative is to represent the environmental uses of water by minimum environmental flow requirements (Jenkins and Lund 2000; Girard et al. 2015). This is the approach taken in this study for the environmental component.

In the Ebro basin, the Water Plan establishes different environmental flows for the different river reaches in the basin. The most important environmental flow is in fact the one established for the Ebro mouth because it affects the 'Delta del Ebro', which is the main ecosystem in the basin, and all upstream water uses in the basin, including those of ecosystems. To analyze the impact of the environmental flow at the mouth, a constraint of minimum mouth flow is added 
into our model. This constraint changes under the different scenarios that combine water availability in the basin and environmental flows at the mouth.

In this study, the baseline environmental flow is the current level established in the Ebro Water Plan of 2015 [Water Plan], setting a minimum flow of $3000 \mathrm{Mm}^{3} /$ year. Two other environmental flow levels are the two lobbied for by the Agencia Catalana del Agua in 2007 [ACA (2007)] and 2015 [ACA (2015)]. The ACA is the water agency in Cataluña, which is the downstream state in the Ebro basin. The ACA (2007) called for a minimum flow of $9482 \mathrm{Mm}^{3}$ in normal years and $7149 \mathrm{Mm}^{3}$ during drought years. The ACA (2015) called for a minimum flow of $7550 \mathrm{Mm}^{3}$ in normal years and $5870 \mathrm{Mm}^{3}$ in drought years (Fig. 1).

Figure 1 shows the historical Ebro river flows at the mouth, together with the environmental flow proposals. It is important to mention that the proposal of the minimum environmental flow made by the Cataluña water agency in 2007 is incompatible with the hydrologic conditions of the Ebro basin. This is because the $9482 \mathrm{Mm}^{3}$ minimum flow proposal in normal years is above $9.000 \mathrm{Mm}^{3}$, which is the average flow observed during the last thirty years. Such a proposal would likely shut down a significant share of economic activities in all regions of the basin.

\subsection{Policy Analysis and Environmental Flows}

The model optimizes the total basin benefits subject to the hydrological, technical and environmental constraints of all water sectors and spatial locations. The optimization equation is as follows:

$$
\operatorname{Max} \sum_{l} B_{l} \forall l=k, u
$$

subject to the constraints of equations (1)-(3), (5)-(8) and (11)-(12), where $B_{l}$ are the benefits of each demand node $l$, including the irrigation districts and urban centers.

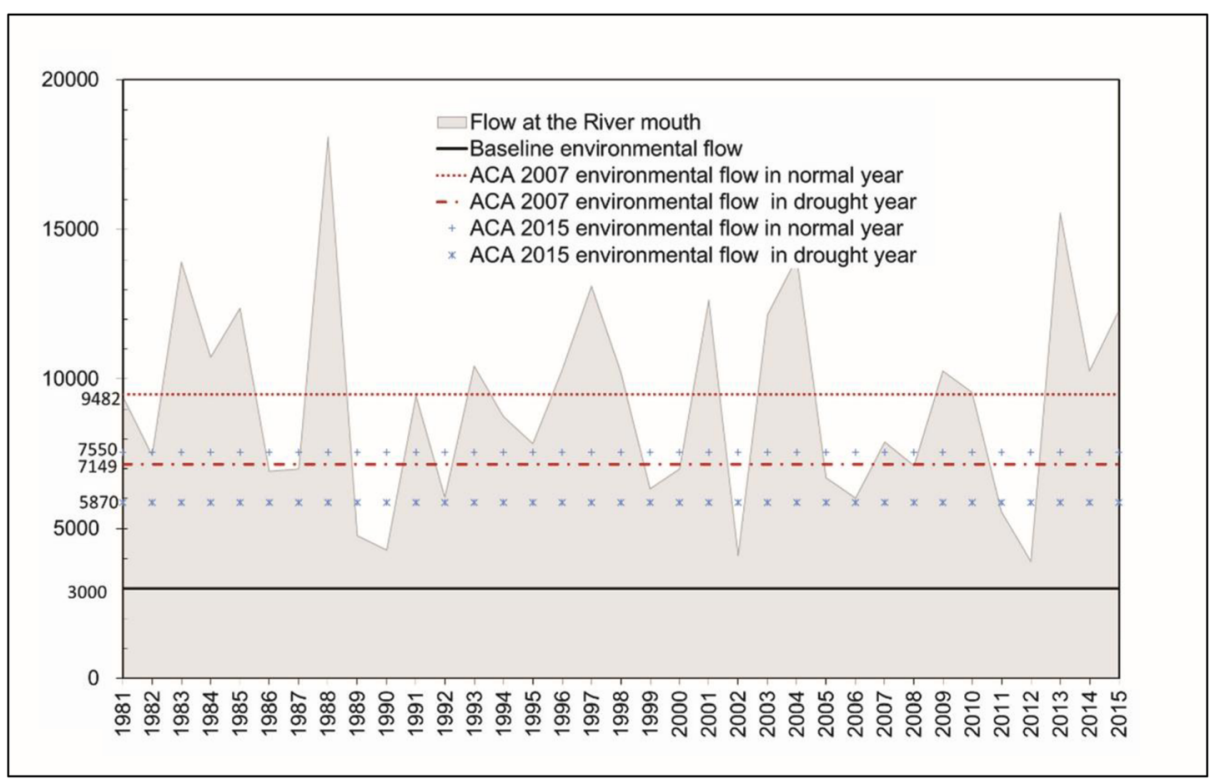

Fig. 1 Ebro River flow and minimum environmental flow at the mouth $\left(\mathrm{Mm}^{3}\right)$. Source: CHE (2016) 
The hydroeconomic model of the Ebro basin is used to analyze the impacts of the different levels of environmental flow at the river mouth (Water Plan, ACA 2007 and ACA 2015). Additionally, we include three water availability scenarios, including normal, moderate and severe drought conditions, to simulate the economic impacts of imposing different environmental flows under diverse hydroclimatic conditions. The combination of scenarios is presented in Figure SM2.2 (Online Supplementary Material). The inflows to the system under normal climate conditions are set at $14,600 \mathrm{Mm}^{3}$, which are the mean inflows for the period 2000-2014 (CHE 2015). Under moderate and severe drought conditions, the basin inflows are reduced by $30 \%$ and $40 \%$ with respect to flows under normal climate conditions, respectively.

The environmental flow of $3000 \mathrm{Mm}^{3}$ at the mouth for normal and drought years established by the Water Plan is the baseline scenario. In the case of drought, the basin authority reduces water allocations proportionally for all irrigation uses in the basin to satisfy the urban uses, which have the highest priority, and the environmental flow constraint of $3000 \mathrm{Mm}^{3}$. Three water allocation policies are considered to analyze the ACA (2007) and ACA (2015) proposals of environmental flow when water availability decreases because of drought: 1) proportional sharing, 2) water markets, and 3) priority of water use given to upstream regions. The proportional sharing policy is the current policy enforced by the Ebro Water Authority during droughts. When there is water scarcity, water allocations in every basin location are reduced proportionally to the shortfall. The water market policy would allow water transfers between willing buyers and sellers, leading to private benefit gains. The policy of prioritizing water use in the upstream regions is as follows: if the downstream state (Cataluña) wants to increase the environmental flow at the mouth above $3000 \mathrm{Mm}^{3}$ during periods of drought, the required water must come first from curtailing downstream use of irrigation in the Cataluña region. These alternative allocation policies are expected to result in different benefit outcomes for stakeholders in downstream and upstream states.

\section{Results}

\subsection{Baseline Scenario of Environmental Flow and Proportional Allocation Policy}

The results of the water allocations and benefits under the baseline scenario of environmental flow $\left(3000 \mathrm{Mm}^{3}\right)$ are presented in Table 1, showing the allocation of irrigation water by crop and irrigation technology. For normal climate conditions, the irrigated area is 528,000 ha divided between field crops (399,000 ha), fruit trees (104,000 ha), and vegetables (25,000 ha). By irrigation technology, 280,000 ha are under surface irrigation, 170,000 ha are under sprinkle irrigation, and 78,000 ha are under drip irrigation. The total water diversion reaches $5400 \mathrm{Mm}^{3}$. Employment is 31,500 annual work units, and the net income generated is 635 million Euros.

During drought periods, the Basin Authority reduces the water allocated to irrigation districts proportionally, while allocation to urban centers is maintained. The provision of water to urban centers has priority over any other use, including environmental flows. The urban use of water is maintained in all scenarios, and the social surplus from urban use is almost 1900 million Euros. Under moderate drought, water allocation to irrigation is reduced by $30 \%$, down to $3780 \mathrm{Mm}^{3}$. The effects of this reduction are a smaller irrigated area $(349,000 \mathrm{ha})$ and lower net income (484 million $€$ ) and labor (26,100 AWU). The environmental flow at the river mouth is $5710 \mathrm{Mm}^{3}$, well above the minimum environmental flow established at $3000 \mathrm{Mm}^{3}$. 


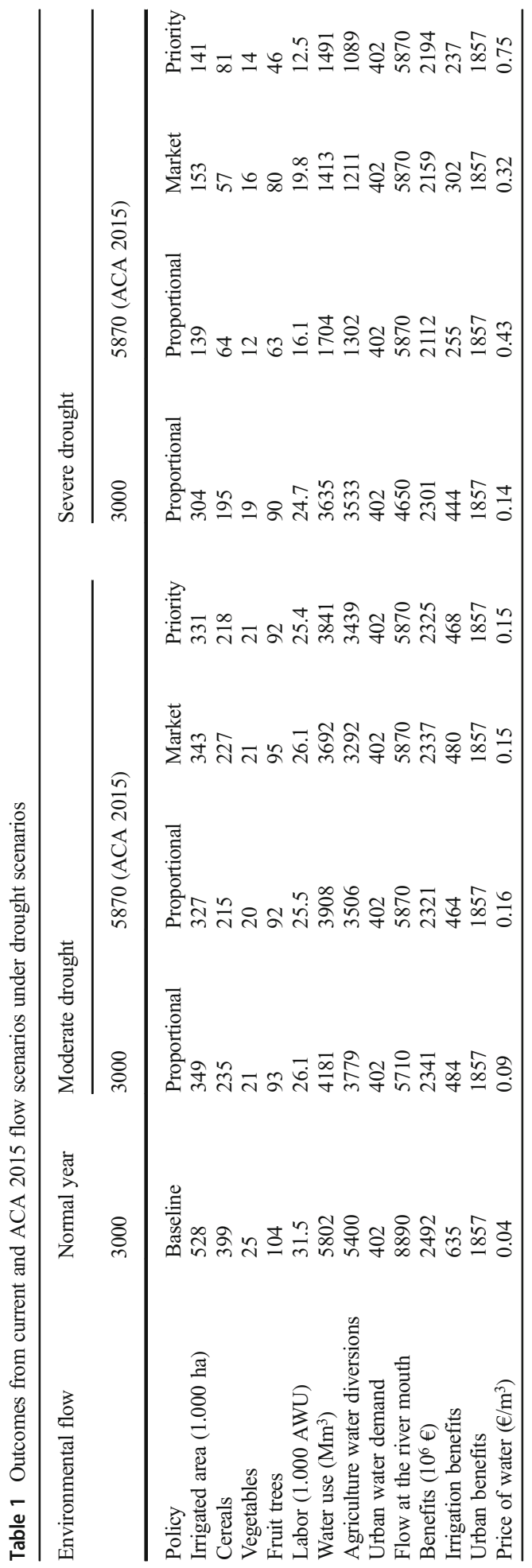


Under a more extreme drought scenario, water allocation to irrigation is reduced by $40 \%$, down to $3530 \mathrm{Mm}^{3}$, with further reductions in the irrigated area (304,000 ha), net income (444 million $€$ ), and labor (24,700 AWU). The production of field crops falls by half because of their low profitability and high water requirements. The environmental flow at the river mouth is $4650 \mathrm{Mm}^{3}$, which is also above the current minimum flow.

The results under moderate and severe drought scenarios show that in both cases, the current $3000 \mathrm{Mm}^{3}$ level of environmental flow is fulfilled. The proportional sharing policy distributes water shortages evenly among all irrigation districts in the basin, and the costs of drought are between 150 and 190 million Euros per year. These results suggest that the current water allocation regime in the Ebro basin is able to balance economic activities with the environmental flow requirements of ecosystems, and this balance is maintained under different levels of water availability.

\subsection{ACA (2015) and ACA (2007) Environmental Flow Proposals under Different Allocation Policies}

Under normal climate conditions, the proposed environmental flows are $9480 \mathrm{Mm}^{3}$ by the ACA (2007) and $7550 \mathrm{Mm}^{3}$ by the ACA (2015). These large increases over the current minimum environmental flows $\left(3000 \mathrm{Mm}^{3}\right)$ imply that more than half of the basin inflows have to be reserved for mouth streamflows in normal years. The ACA (2007) environmental flow is slightly above the $9000 \mathrm{Mm}^{3}$ average flow in the river, so it would be almost feasible in normal years. The ACA (2015) environmental flow is below the average flow, so it is fully feasible in normal years. The ACA environmental flow scenarios are simulated only under moderate or severe drought because in normal years, environmental flows are above the requested thresholds.

The problem with the ACA claims appears clearly during drought years because the flow at the mouth is only $5710 \mathrm{Mm}^{3}$ under moderate drought and $4650 \mathrm{Mm}^{3}$ under severe drought. The ACA-requested drought minimum flow requirements of $7150 \mathrm{Mm}^{3}$ (ACA (2007)) and $5870 \mathrm{Mm}^{3}$ (ACA (2015)) cannot be fulfilled, even under moderate drought, without curtailing the economic activities of the basin to reallocate water into the Ebro mouth. Since urban use has the highest priority, the shortfall during droughts to comply with the ACA requests requires the reduction of irrigation activities in the basin.

Three alternative water allocation policies are considered during droughts for water reallocation from irrigation into the Ebro streamflow to satisfy the ACA requests for flow in the Ebro mouth: proportional sharing, water market, and priority of water use given to upstream regions.

\subsubsection{Water Allocation Policies under the ACA (2015) Proposal and Droughts}

Proportional Sharing Irrigation allocations are fixed shares of the available water in the basin, and they fall under drought scenarios. To satisfy the ACA environmental flow of $5870 \mathrm{Mm}^{3}$ at the mouth during drought, the proportional sharing involves reducing irrigation water to $3506 \mathrm{Mm}^{3}$ in moderate drought ( $-35 \%$ of baseline) and to $1302 \mathrm{Mm}^{3}$ in severe drought ( $-76 \%$ of baseline) (Table 1$)$. The irrigated area falls sharply, mostly affecting low-profit field crops and less efficient surface irrigation technologies. Benefit losses to farmers are also strong from 171 million Euros in moderate drought ( $-27 \%$ of baseline) to 380 million Euros in severe drought ( $-60 \%$ of baseline). The losses sustained by farmers are evenly distributed among all irrigation districts in the basin. 
Water Market Irrigation districts receive their allocation share, and water trading between districts maximizes their joint benefits. Irrigation water use is reduced to $3292 \mathrm{Mm}^{3}$ under moderate drought $\left(-39 \%\right.$ of baseline) and to $1211 \mathrm{Mm}^{3}$ under severe drought $(-77 \%$ of baseline). The irrigated area with the water market policy is larger than the area cultivated with the proportional sharing policy. Benefit losses range between 155 million Euros in moderate drought ( $-25 \%$ of baseline) and 333 million Euros in severe drought ( $-52 \%$ of baseline). Farmers would prefer water markets over proportional sharing allocation because of the higher benefits. The irrigation districts specializing in fruit trees and vegetables experience lower losses than districts specializing in field crops.

Priority of Upstream Regions Cataluña is the downstream state asking for a steep increase in the environmental flow at the Ebro mouth. This policy places the burden of the water reallocation on the region requesting the reallocation of water from economic activities to the environment, rather than on the upstream regions. The reallocation effort is made first by the irrigation districts located in the downstream region, and then any additional reallocation to meet the environmental flow at the mouth is made by the upstream regions. Under moderate drought, irrigation water in the basin falls to $3439 \mathrm{Mm}^{3}$ ( $-36 \%$ of baseline), and the burden of the water reallocation is supported by the downstream region. In this region, the reduction of irrigation water with respect to the baseline is $45 \%, 30 \%$ because of the drought and $15 \%$ to cover the $5870 \mathrm{Mm}^{3}$ environmental flow requirements. The reduction in upstream regions is $30 \%$ to cover the drought-induced water shortfall.

Under severe drought, the use of irrigation water at the basin level is $1089 \mathrm{Mm}^{3}$, which feeds 103,000 ha of crop production. All irrigation water in Cataluña is reallocated to the environmental flow at the Ebro mouth, while in upstream irrigation districts, the use of water falls by $65 \%$ with respect to the baseline, compared to $76 \%$ under the proportional sharing policy. There is a full loss of benefits in Cataluña amounting to 167 million Euros with respect to the baseline. In the upstream regions, the benefit loss is 233 million Euros. This loss is 50\% of the baseline compared to $60 \%$ under the proportional sharing policy. The policy of priority of upstream regions during severe droughts is extremely costly to Cataluña in order to maintain the $5870 \mathrm{Mm}^{3}$ environmental flow requirement, but it is also very costly for upstream regions that are against raising the environmental flow requirement. If Cataluña wants to raise the environmental flow from $3000 \mathrm{Mm}^{3}$ to $5870 \mathrm{Mm}^{3}$ during severe drought years, the rest of the regions could ask Cataluña for compensation for their losses. This compensation would amount to 91 million Euros, which is the benefit difference in upstream regions under severe drought between having the $3000 \mathrm{Mm}^{3}$ threshold (328 million $€$ ) and having the $5870 \mathrm{Mm}^{3}$ threshold (237 million $€$ ) (Table 2). Then, under the policy of upstream priority and compensation to upstream states, the total costs for Cataluña of raising the environmental flow threshold would be 207 million Euros, the sum of the loss of 116 million from the upstream priority policy, plus the 91 million of compensation to upstream farmers.

\subsubsection{Water Allocation Policies under the ACA (2007) Proposal and Droughts}

Under moderate drought, the ACA (2007) claim of increasing environmental flow from 3000 to $7150 \mathrm{Mm}^{3}$ cuts the farmers benefits by more than half with respect to a normal year for the three allocation policies, falling from 635 to between 260 and 320 million Euros (Table SM2.3 in Online Supplementary Material). By expanding the environmental flow from the current 
Table 2 Upstream and downstream benefits under flow scenarios by climate $\left(10^{6} €\right)$

\begin{tabular}{|c|c|c|c|c|c|c|}
\hline \multirow[t]{4}{*}{ Environmental flow/Policy } & \multicolumn{6}{|l|}{ Climate } \\
\hline & \multicolumn{3}{|c|}{ Moderate drought } & \multicolumn{3}{|c|}{ Severe drought } \\
\hline & \multicolumn{3}{|l|}{ Region } & \multicolumn{3}{|l|}{ Region } \\
\hline & Upstream & Downstream & Basin & Upstream & Downstream & Basin \\
\hline \multicolumn{7}{|l|}{ Baseline $\left(3000 \mathrm{Mm}^{3}\right)$} \\
\hline Proportional & 357 & 127 & 484 & 328 & 116 & 444 \\
\hline \multicolumn{7}{|l|}{ ACA $2015\left(5870 \mathrm{Mm}^{3}\right)$} \\
\hline Proportional & 342 & 122 & 464 & 185 & 70 & 255 \\
\hline Market & 359 & 121 & 480 & 229 & 73 & 302 \\
\hline Upstream priority & 357 & 111 & 468 & 237 & 0 & 237 \\
\hline \multicolumn{7}{|l|}{ ACA $2007\left(7150 \mathrm{Mm}^{3}\right)$} \\
\hline Proportional & 202 & 75 & 277 & Unfeasible $^{\mathrm{a}}$ & Unfeasible & Unfeasible \\
\hline Market & 245 & 79 & 324 & Unfeasible & Unfeasible & Unfeasible \\
\hline Upstream priority & 258 & 0 & 258 & Unfeasible & Unfeasible & Unfeasible \\
\hline
\end{tabular}

a: "Unfeasible" indicates that there is no solution under severe drought because the environmental flow can not be reached even by cutting off all irrigation in the basin

3000 to $7150 \mathrm{Mm}^{3}$ during drought, the percentage of farmers' losses doubles to more than $50 \%$ under any allocation policy. Under severe drought, the ACA (2007) environmental flow request is unfeasible, which means that the $7150 \mathrm{Mm}^{3}$ of environmental flow cannot be achieved even by cutting all irrigation use in the basin. These results indicate that the ACA (2007) proposal of environmental flow under drought is untenable. This is not only because this flow level is impossible to achieve under severe drought but also because under moderate drought, the massive losses to farmers would make this flow request politically unfeasible.

Table 2 summarizes the results by showing the benefits to upstream and downstream regions from the three water allocation policies under the environmental flow scenarios and climate conditions. Implementing the ACA (2015) proposal and the policy of upstream priority under moderate drought will maintain the benefits of upstream regions in relation to the baseline at 357 million Euros, but under severe drought, the benefits of upstream regions fall by 91 million Euros with respect to the baseline. Implementing the ACA (2007) proposal and the policy of upstream priority under moderate drought will reduce the benefits of upstream regions by 99 million Euros, and this environmental flow proposal is unfeasible under severe drought.

Considering both the ACA (2015) and ACA (2007) proposals, the main outcomes from the three allocation policies are the following: i) raising the environmental flow of the Ebro mouth escalates the loss of economic benefits during droughts, and the losses become extremely large during severe droughts; ii) the water market policy is an alternative policy that could achieve higher benefits under both moderate and severe droughts; iii) the bulk of the negative impact of raising the environmental flow requirements under droughts is supported by the farmers of field crops; and iv) the proportional sharing policy distributes the benefit losses evenly among all basin regions, achieving higher total basin benefits compared to the upstream priority policy. However, the upstream regions could obtain higher benefits with the upstream priority policy than with the proportional sharing policy (Fig. 2). 


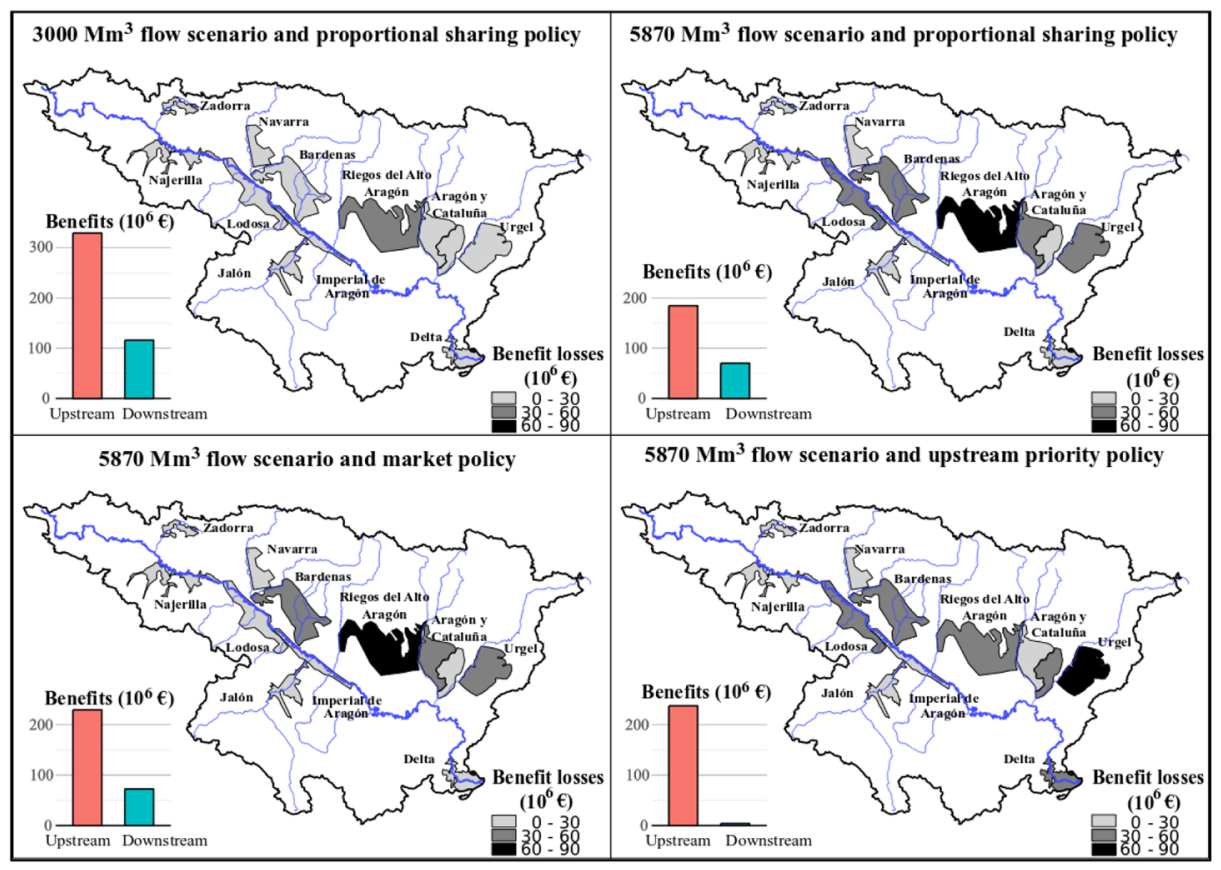

Fig. 2 Benefits for the current (3000) and ACA 2015 (5870) flow scenarios, under severe drought $\left(10^{6} €\right)$. Benefit losses are calculated with respect to the baseline (normal year)

\section{Discussion}

This paper aims to evaluate the tradeoffs and political economy aspects of allocating water among water use sectors and environmental flows in water-scarce river basins. To achieve this objective, we developed a hydroeconomic model applied to the Ebro basin of Spain as a case study, where an intense debate on environmental flow allocation in the Ebro mouth is taking place. The hydroeconomic model is used to analyze three scenarios of environmental flow at the river mouth under normal and drought climatic conditions. The environmental flow scenarios are the current flow of $3000 \mathrm{Mm}^{3}$ established by the Ebro Water Plan and the ACA 2007 and 2015 proposals of the downstream state (Cataluña), which require raising the minimum environmental flow at the Ebro mouth two to three times. Additionally, three water allocation policies (proportional sharing, water markets, and upstream priority) have been simulated to analyze different mechanisms of sharing the costs imposed by raising the current environmental flow.

The simulation results show that under the current environmental flow requirement of $3000 \mathrm{Mm}^{3}$ (Water Plan), drought events generate important losses of economic benefits to farmers. The adaptation of irrigation districts to drought consists of modifying the crop production pattern towards the more profitable crops and the use of efficient irrigation systems. The results also indicate that the current minimum environmental flow requirement at the river mouth (i.e., Water Plan) does not restrict the economic activities in the basin under any climatic condition and enables more flexible water management in the future (e.g., expansion of the irrigated area or hydropower production).

Accepting the requests of Cataluña and raising the minimum environmental flow at the Ebro mouth by two to three times would significantly increase the loss of benefits to farmers during 
droughts. The magnitude of these losses depends on the water allocation policy chosen. The comparison between these policies during droughts shows that the water market policy is the most efficient policy intervention, achieving the highest total basin economic benefits. The policy of proportional sharing achieves higher total basin benefits compared to the policy of priority of upstream regions in almost all scenarios, and it distributes the economic losses evenly among regions in the basin. However, the proportional sharing policy results in lower benefits in upstream regions compared to the other policies in all scenarios. The policy of upstream priority places the burden of adjusting to higher environmental flow requirements on the downstream region of Cataluña, which therefore improves the benefits of upstream regions.

The reason behind the policy of upstream priority is that the downstream state of Cataluña is asking for a steep increase of between two and three times the current environment flow requirement, and upstream states, which will sustain large economic losses, are not willing to accept this proposal. The policy of upstream priority therefore shifts the costs of reaching the higher environmental flow towards the downstream region requesting it rather than spreading the costs evenly among all regions in the basin (i.e., proportional sharing). Hence, the reallocation effort is made first by the irrigation districts downstream, and then any additional reallocation to meet the environmental flow requirement is made by the upstream regions. Our results indicate that the proposal by Cataluña of increasing environmental flows is very costly to farmers in other states of the basin. This negative impact could be partly mitigated by implementing a water allocation policy that prioritizes the upstream regions, but benefits will still be lost in some cases. One possibility to gain the support of these regions is by providing payments from the Cataluña downstream state to the upstream states to compensate for any remaining losses they sustain because of the increase of environmental flow at the Ebro mouth.

These empirical findings from the Ebro basin show the potential tradeoffs and political economy challenges of the reallocation of water from water use sectors to the environment, which may entail important lessons for other river basins in the world that face similar water scarcity problems and span multiple jurisdictions, such as the case of the transboundary basins of the Nile, Colorado, Indus, and Amu and Syr Daria Rivers. The results of this study indicate that the reallocation of scarce water resources from water use sectors to the environment, well above the existing environmental flow threshold, could have disproportionate costs for farmers and further constrain adaptation to climate change impacts (e.g., droughts). Some stakeholder groups could be especially affected by increasing environmental flow requirements, and their opposition may undermine any attempt at water reallocation to the environment. Water allocation policies could help mitigate economic losses and evenly distribute these losses among all stakeholder groups. The choice of efficient and equitable policy interventions that minimize the tradeoffs and offset stakeholder interests would likely reduce the likelihood of failure of water reallocation to the environment. As a final remark, the results of this study show the importance of having reliable assessments of environmental flow requirements in water-scarce river basins. Therefore, water management authorities in these basins should invest in generating reliable hydrological and socioeconomic information through measurements and use of model simulations.

\section{Conclusions}

There is a growing concern in societies across the world regarding the escalating water scarcity in basins located in arid and semiarid regions. Global human water demands have been 
increasing rapidly, which has resulted in severe ecosystem degradation. The emerging social demands for environmental protection in the form of secured minimum environmental flows for water-dependent ecosystems and climate change impacts will further increase the competition for already scarce water resources in many basins worldwide.

This study evaluates the tradeoffs and political economy aspects of allocating water among economic water uses and environmental flows in water-scarce river basins that cover multiple jurisdictions. We used a hydroeconomic model applied to the Ebro basin of Spain as an illustrative case study. The results of this application highlight the importance of assessing the opportunity costs and political implications of reallocating water from economic activities to the environment under the impending climate change impacts. Moreover, the results indicate that the policy interventions used to share the costs imposed by droughts and raising environmental flow requirements should be not only economically efficient but also socially acceptable to reduce the likelihood of failure of water reallocation to the environment.

Acknowledgments This study has been financed by the project INIA RTA2014-00050-00-00 from the Spanish Ministry of Science, Innovation and Universities, which includes partial funding from the European Regional Development Fund, and by support funding to the research group ECONATURA from the Government of Aragon. Regarding individuals, special assistance has been provided by María Ángeles Lorenzo and Daniel Isidoro (CITA-DGA), Pablo Bruna (CTA-DGA), Rogelio Galván and Miguel Ángel García Vera (CHEMITECO).

\section{Compliance with Ethical Standards}

Conflict of Interest The authors declare that they have no conflicts of interest.

Open Access This article is distributed under the terms of the Creative Commons Attribution 4.0 International License (http://creativecommons.org/licenses/by/4.0/), which permits unrestricted use, distribution, and reproduction in any medium, provided you give appropriate credit to the original author(s) and the source, provide a link to the Creative Commons license, and indicate if changes were made.

\section{References}

Acreman M (2016) Environmental flows-basics for novices: environmental flows. Wiley Interdiscip Rev Water 3(5):622-628. https://doi.org/10.1002/wat2.1160

Agencia Catalana del Agua (ACA) (2007) Propuesta de caudales ambientales en el tramo final del río Ebro. Generalitat de Catalunya, Barcelona

Agencia Catalana del Agua (ACA) (2015) Revisió i actualització de la proposta de règim de cabals ecològics al tram final del riu Ebre, delta i estuari. Generalitat de Catalunya, Barcelona

Ahmadi A, Karamouz M, Moridi A, Han D (2012) Integrated planning of land use and water allocation on a watershed scale considering social and water quality issues. J Water Resour Plan Manag 138:671-681. https://doi.org/10.1061/(ASCE)WR.1943-5452.0000212

Albiac J (2017) Review on the Political Economy of Water Reforms in Agriculture. Working Document 17/01. Department of Agricultural Economics. CITA, Zaragoza https:/citarea.cita-aragon.es/citarea/handle/10532/3663

Arbués F, Barberán R, Villanúa I (2004) Price impact on urban residential water demand: a dynamic panel data approach. Water Resour Res 40(11):24-30. https://doi.org/10.1029/2004WR003092

Arbués F, García-Valiñas MÁ, Villanúa I (2010) Urban water demand for service and industrial use: the case of Zaragoza. Water Resour Manag 24(14):4033-4048. https://doi.org/10.1007/s11269-010-9645-5

Arthington A (2012) Environmental flows: saving Rivers in the third Millenium. University of California Press, Berkeley

Biemans H, Haddeland I, Kabat P, Ludwig F, Hutjes R, Heinke J, von Bloh W, Gerten D (2011) Impact of reservoirs on river discharge and irrigation water supply during the 20th century. Water Resour Res 47: W03509. https://doi.org/10.1029/2009WR008929 
Booker J, Howitt R, Michelsen A, Young R (2012) Economics and the modeling of water resources and policies. Natural Resources Modeling 2012(25):168-218. https://doi.org/10.1111/j.1939-7445.2011.00105.x

Centro de Estudios y Experimentación de Obras Públicas (CEDEX) (2016) Anuario de Aforos 2013-2014, Dirección General del Agua. MAPAMA, Madrid

Confederación Hidrográfica del Ebro (CHE) (2007) Plan Especial de Actuación en Situaciones de Alerta y Eventual Sequía, Memoria CHE. MIMAM, Zaragoza

Confederación Hidrográfica del Ebro (CHE) (2009) Memoria 2009. CHE. MARM, Zaragoza

Confederación Hidrográfica del Ebro (CHE) (2015) Plan Hidrológico de la Demarcación Hidrográfica del Ebro, Memoria CHE. MAGRAMA, Zaragoza

Confederación Hidrográfica del Ebro (CHE) (2016) Prospecto del Plan Hidrológico de la Demarcación Hidrográfica del Ebro. MAPAMA, Zaragoza

Connor J, Franklin B, Loch A, Kirby M, Wheeler S (2013) Trading water to improve environmental flow outcomes. Water Resour Res 49:4265-4276. https://doi.org/10.1002/wrcr.20323

Dagnino M, Ward F (2012) Economics of agricultural water conservation: empirical analysis and policy implications. Int J Water Resour Dev 28:577-600. https://doi.org/10.1080/07900627.2012.665801

Generalitat de Catalunya (GC) (2009) Superfícies Municipals dels Conreus Agrícoles, Any 2009. Departament d'Agricultura, Ramaderia, Pesca, Alimentació i Medi Natural, Barcelona.

Girard C, Rinaudo J, Pulido-Velazquez M, Caballero Y (2015) An interdisciplinary modelling framework for selecting adaptation measures at the river basin scale in a global change scenario. Environl Model Softw 69: 42-54. https://doi.org/10.1016/j.envsoft.2015.02.023

Gobierno de Aragón (DGA) (2009) Base de datos 1T de superficies de cultivos por término municipal 2009. Departamento de Desarrollo Rural y Sostenibilidad, Zaragoza

Gobierno de Navarra (GN) (2009) Base de datos 1T de superficies de cultivos por término municipal 2009, Departamento de Desarrollo Rural. Medio Ambiente y Administración Local, Pamplona

Greve P, Kahil T, Mochizuki J, Schinko T, Satoh Y, Burek P, Fischer G, Tramberend S, Burtscher R, Langan S, Wada Y (2018) Global assessment of water challenges under uncertainty in water scarcity projections. Nat Sustain 1:486-494. https://doi.org/10.1038/s41893-018-0134-9

Instituto Nacional de Estadística (INE) (2009) Censo Agrario 2009. INE, Madrid

Jenkins M, Lund J (2000) Integrating yield and shortage management under multiple uncertainties. J Water Resour Plan Manag 126:288-297. https://doi.org/10.1061/(ASCE)0733-9496(2000)126:5(288

Liu J, Yang H, Gosling S, Kummu M, Flörke M, Pfister S et al (2017) Water scarcity assessments in the past, present, and future. Earth's Future 5(6):545-559. https://doi.org/10.1002/2016EF000518

Ministerio de Agricultura y Pesca, Alimentación y Medio Ambiente (MAGRAMA) (2016) Anuario de Estadística 2015. MAGRAMA, Madrid

Ministerio de Medio Ambiente, Rural y Marino (MARM) (2010) Resultados técnico-económicos de explotaciones agrícolas de Aragón en 2009. MARM, Madrid

Momblanch A, Connor J, Crossman N, Paredes-Arquiola J, Andreu J (2016) Using ecosystem services to represent the environment in hydro-economic models. J Hydrol 538:293-303. https://doi.org/10.1016/j. jhydrol.2016.04.019

Yan D, Yao M, Ludwig F, Kabat P, Huang HQ, Hutjes RWA, Werners SE (2018) Exploring future water shortage for large river basins under different water allocation strategies. Water Resour Manag 32(9):3071-3086. https://doi.org/10.1007/s11269-018-1975-8

Publisher's Note Springer Nature remains neutral with regard to jurisdictional claims in published maps and institutional affiliations.

\title{
Affiliations
}

\section{Daniel Crespo ${ }^{1} \cdot$ Jose Albiac ${ }^{1} \cdot$ Taher Kahil $^{2} \cdot$ Encarna Esteban $^{3} \cdot$ Safa Baccour $^{1}$}

\author{
Daniel Crespo \\ crespo976@hotmail.com
}

Taher Kahil

kahil@iiasa.ac.at 


\section{Encarna Esteban}

encarnae@unizar.es

\section{Safa Baccour}

baccour.safa@gmail.com

1 Department of Agricultural Economics, CITA and Universidad de Zaragoza-IA2, Avenida Montañana 930, 50059 Saragossa, Spain

2 International Institute for Applied Systems Analysis-IA2, Laxenburg, Austria

3 School of Social Sciences and Humanities, Universidad de Zaragoza-IA2, Teruel, Spain 